Urgensitas Keluarga Dalam Menanamkan Nilai-Nilai

\title{
URGENSITAS KELUARGA DALAM MENANAMKAN NILAI-NILAI PENDIDIKAN KEAGAMAAN PADA ANAK
}

\author{
Asnawan \\ Dosen IAI Al Falah As Sunniyyah Kencong Jember \\ Email: asnawan@inaifas.ac.id
}

\begin{abstract}
Development of the child's age phase. While for families who are less able in their religious knowledge, children's education is left to the Koran teacher. The role of the family in this case is nothing but a motivator for children. The role of the family in instilling worship values in children in the family is huge. The role appears in the efforts of parents to always instill the values of worship and at the same time train children to have a high personality in carrying out their worship. The role of the family in instilling moral values in children is also very large. This form of planting is started by parents starting early.
\end{abstract}

Keywords: Family Education, Diversity Values, Children.

\begin{abstract}
Abstrak
Perkembangan fase usia anak. Sementara bagi keluarga yang kurang mampu dalam pengetahuan agamanya, maka pendidikan anak diserahkan pada guru ngaji. Peranan keluarga dalam hal ini tidak lain sebagai motivator bagi anak. Peranan keluarga dalam menanamkan niali-nilai- ibadah pada anak di dalam keluarga amatlah besar. Peranan tersebut nampak pada usaha yang dilakuakan orang tua untuk selalu menanamkan nilai-nilai ibadah serta sekaligus melatih anak agar mempunyai kepribadian yang tinggi dalam menjalankan ibadahnya. Peranan keluarga dalam menanamkan nilai-nilai akhlak pada anak juga amatlah besar. Bentuk penanaman ini di mulai oleh orang tua mulai sejak dini.
\end{abstract}

Kata Kunci: Pendidikan Keluarga, Nilai-Nilai Keagaman, Anak.

\section{PENDAHULUAN}

Di dalam keluarga, setiap orang tua menginginkan anak yang dilahirkannya menjadi orang-orang yang berkembang secara sempurna. Mereka tentu menginginkan agar anak yang dilahirkan menjadi orang yang cerdas, pandai serta menjadi orang yang beriman kepada Tuhannya. Artinya dalam taraf yang sangat sederhana, orang tua tidak ingin anaknya menjadi generasi yang nakal serta jauh dari nilai-nilai pendidikan agama Islam.

Vol. ㄱ. No. 02. Dktober 2019

Jurnal Auladuna | 127 
Asnawan

Untuk mencapai tujuan itu, maka seharusnya orang tua menyadari tentang arti pentingnya pendidikan bagi anak-anaknya khususnya pendidikan yang ada sangkut pautnya dengan nilai-nilai pendidikan agama Islam. Karena itu semua merupakan tanggung jawab orang tua terhadap generasi yang dilahirkannya. Sehubungan dengan tanggung jawab ini, maka seharusya orang tua dapat mengetahui mengenai apa dan bagaimana pendidikan dalam keluarga. Karena keluarga sendiri menurut Zakiyah Darajat "merupakan masyarakat alamiah yang pergaulan di antara anggotanya bersifat khas. Dalam lingkungan ini terletak dasar-dasar pendidikan, di sini pendidikan berlangsung dengan semdirinya sesuai dengan tatananan pergaulan yang berlaku didalamnya". ${ }^{1}$

Di dalam UU No 20 Tahun 2003 tentang sistem pendidikan nasional pasal 7 ayat 1 dinyatakan bahwa "orang tua berperan serta dalam memilih satuan pendidikan dan memperoleh informasi tentang perkembangan anaknya". Sementara itu pasal 7 ayat 2 dinyatakan pula bahwa "orang tua dari anak usia wajib belajar, berkewajiban memberikan pendidikan dasar kepada anaknya". Jadi dari sini jelas bahwa pendidikan adalah tanggung jawab bersama baik antara keluarga, masyarakat dan pemerintah.

Oleh karena itu lembaga pendidikan keluarga selaku pendidikan yang paling bertanggung jawab terhadap anak-anaknya, hendaknya selalu memperhatikan dan membimbing anak-naknya khususnya bimbingan dan didikan yang berhubungan dengan nilai-nilai pendidikan agama Islam karena itu merupakan kunci. Mengapa kunci? karena pendidikan agamalah yang berperan besar dalam membentuk pandangan hidup seseorang. Jadi dalam hal ini jelas bahwa pembangunan sumber daya manusia, termasuk pembinaan anak, erat sekali kaitannya dengan penumbuhan nilai-nilai seperti takwa kepada Tuhan, jujur, disiplin, dan memiliki etos kerja yang tinggi. Hal ini bukanlah suatu proses sesaat, melainkan suatu proses yang panjang yang harus dimulai sedini mungkin, yaitu sejak masa anak-anak. Dengan menumbuhkan anak-anak sejak dini, akan lahirlah generasi anak Indonesia yang berkualitas.

Pendidikan untuk menghasilkan manusia yang berkualitas itu sangat penting bagi manusia pada zaman kemajuan yang serba cepat ini, lebih-lebih pada abad yang akan datang. Dari sekarang telah terasa kuatnya persaingan antara orang perorang, antara kelompok, juga

\footnotetext{
${ }^{1}$ Zakiyah Daradjat, 1996, Ilmu Pendidikan Islam, Jakarta; Bumi Aksara, hal.89

${ }^{2}$ Sisdiknas, 2003, UU. RI No. 20 Tahun 2003, Bandung; Citra Umbara. hal.07
}

Jurnal Auladuna | 128

Vol. ㄱ. №. Q2. Tktober 2019 
Urgensitas Keluarga Dalam Menanamkan Nilai-Nilai antar bangsa agar mampu bertahan dalam kehidupan yang serba dinamis. Hidup pada zaman seperti itu tidaklah mudah anak-anak harus disiapkan sedini mungkin, terarah, teratur, dan berdisiplin. Dalam kehidupan seperti itu godaan dan hal-hal yang dapat merusak mental serta moral manusia sungguh amat dahysat. Dan menghadapi zaman itu agama akan terasa lebih diperlukan. Oleh karena itulah peranan pendidikan keluarga sangat dibutuhkan sekali dalam menanamkan nilai-nilai pendidikan agama Islam pada anak semenjak dini agar mereka mampu menjadi tunas bangsa yang baik dan berkualitas. Keluarga sendiri menurut para pendidik sebagaimana yang dikutip Jalaluddin dalam bukunya psikologi agama mengatakan bahwa:

Keluarga merupakan lapangan pendidikan yang pertama, dan pendidiknya adalah kedua orang tua. Orang tua (bapak dan ibu) adalah pendidik kodrati. Mereka pendidik bagi anak-anaknya karena secara kodrat ibu dan bapak diberikan anugerah oleh Tuhan pencipta berupa naluri orang tua. Karena naluri ini timbul rasa kasih sayang para orang tua pada anak-anak mereka, sehingga secara moral keduanya merasa terbebani tanggung jawab untuk memelihara, mengawasi dan melindungi serta membimbing keturunan mereka. ${ }^{3}$

Dari pendapat di atas dapat kita ketahui bahwa peranan pendidikan keluarga amatlah penting, apalagi pendidikan keagamaan. Karena pendidikan agama Islam di sini merupakan basic bagi anak-anak dalam rangka sebagai bekal untuk kehidupan mereka selanjutnya. Orang tua selaku pendidik bagi anak-anaknya diharapkan agar selalu berperan aktif dalam menanamkan nila-nilai pendidikan agama Islam pada anak-anaknya. Karena menurut Rasulullah, fungsi dan peranan orang tua mampu membentuk arah dan keyakinan anak-anak mereka. Menurut beliau, "setiap bayi yang dilahirkan sudah memiliki potensi untuk beragama namun bentuk keyakinan agama yang akan dianut sepenuhnya tergantung dari bimbingan, pemeliharaan dan pengaruh kedua orang tua. ${ }^{4}$

\section{PEMBAHASAN}

\section{Pengertian Keluarga}

Pengertian keluarga menurut Hasan Langulung diartikan sebagai berikut:

"Suatu unit sosial yang terdiri dari seorang suami dan seorang istri atau dengan kata lain keluarga adalah perkumpulan halal anatara laki-laki dan seorang perempuan yang

\footnotetext{
${ }^{3}$ Jalaluddin, 2003, Psikologi Agama, Jakarta; PT. Raja Grafindo Persada, hal.216

${ }^{4}$ Hasbullah, 2003, Dasar-Dasar Ilmu Pendidikan, Jakarta; PT. Raja Grafindo Persada, hal.116 Vol. ㄱ․ No. 02. Oktober 2019 
Asnawan

bersifat terus menerus dimana yang satu merasa tentram dengan yang lain sesuai dengan yang ditentukan oleh agama dan masyarakat. Dan ketika kedua seorang istri dikaruniai seorang anak atau lebih, maka anak-nak itu menjadi unsur utama ketiga pada keluarga tersebut disamping dua unsur sebelumnya". 5

Keluarga mempunyai peranan yang besar sekali bagi tumbuh dan berkembangnya seorang anak baik yang berkenaan dengan pertumbuhan intelektual, moral dan agamanya. Menurut beliau di antara peranan orang tua antara lain sebagai berikut:

1. Menjamin Kehidupan Emosional Anak

Melalui pendidikan keluarga kehidupan emosional anak atau kebutuhan akan rasa kasih sayang anak akan dapat terpenuhi dan dapat tumbuh dengan baik hal ini dikarenakan adanya hubungan jalinan darah antara orang tua dan anak di samping fokus dan konsentrasi orang tua lebih ditekankan pada anak.

Kehidupan emosional merupakan faktor yang sangat signifikan dalam membina kepribadian anak. Oleh karenanya pihak orang tua harus mampu menciptakan suasana yang kondusif bagi anak melalui cerminan kasih sayang.

2. Menanamkan Dasar Pendidikan Moral

Penanaman dasar-dasar moral bagi anak dalam keluarga biasanya tercermin dalam sikap dan prilaku orang tua sendiri. Anak akan cenderung mengikuti segala pola dan tingkah laku orang tua. Misalnya cara berbuat dan berbicara. Dengan demikian prilaku yang baik dari orang tua akan melahirkan gejala identifikasi yang positif bagi anak yakni penyamaan diri dengan orang yang ditiru.

\section{Peletak Dasar Keagamaan}

Pada dasarnya agama seseorang ditentukan oleh pendidikan, pengalaman dan latihan-latihan yang dilaluinya pada masa kecil. Seseorang yang waktu kecilnya tidak mendapat pendidikan agama, maka pada dewasanya ia tidak merasa penting akan adanya agama dalam hidupnya. Lain dengan orang yang waktu kecilnya sudah dikenalkan dengan pengalaman-pengalaman agama misalnya kedua orang tuanya taat beragama, ditambah lagi dengan pendidikan sekolah, maka orang tersebut akan dengan sendirinya mempunyai kecenderungan terhadap hidup yang taat mengikuti peraturan-peraturan agama. Di samping itu juga terbiasa

\footnotetext{
${ }^{5}$ Hasan Langulung, , 1995, Manusia Dan Pendidikan, Jakarta, Al-Husna Dzikra, hal.349

Jurnal Auladuna | 130

Vol. ㅁ. №. [2. Iktober 2019
} 
Urgensitas Keluarga Dalam Menanamkan Nilai-Nilai

menjalankan ibadah, takut larangan-larangan dan merasakan betapa nikmatnya hidup beragama.

Menurut Anshari dalam kehidupan keluarga nilai-nilai ajaran agama bagi kehidupan seorang anak akan mempengaruhi dan memberikan dampak yang positif terhadap pembentukan karakter anak sejak ia kecil hingga ia dewasa kelak. Sedangkan menurut Abdul Halim Nipan peranan keluarga dalam memberikan dasar-dasar pendidikan keagamaan pada anak yakni dalam rangka untuk membentuk anak sholeh dan mengharap ridho Allah.

a.) Membentuk anak sholeh berarti anak yang berkepribadian baik dalam menjalin hubungan dengan Allah SWT. dan baik pula dalam berhubungan dengan sesama makhluk ciptaannya, terutama terhadap sesama manusia. Allah SWT. mengisyaratkan dalam hal ini dalam firmannya:

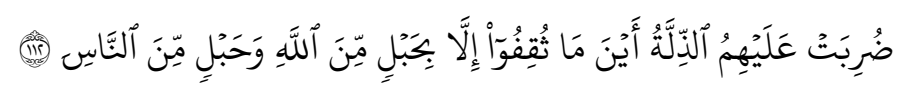

Artinya: "Mereka senantiasa diliputi kehinaan dimanapun berada, kecuali jika mereka berhubungan baik terhadap Allah dan berhubungan baik terhadap sesama manusia ...". (Q.S Ali Imran: 112) (Depag, 1989: 94)

Berdasarkan keterangan ayat di atas manusia selamanya dalam keadaan hina di manapun berada, kecuali jika mau menjalin hubungan baik dengan Allah SWT. maupun dengan sesama manusia. Demikian halnya dengan pengertian anak shaleh.

\section{b.) Mengharap Ridho Allah SWT.}

Manusia termasuk didalamnya para orang tua muslim tidak mampu merubah takdir Ilahi. Manusia hanya berkewajiban berikhtiar, dan Allah-lah yang mentakdirkan segala sesuatunya.

$$
\begin{aligned}
& \text { Rasulullah menegaskan dalam sabdanya: }
\end{aligned}
$$

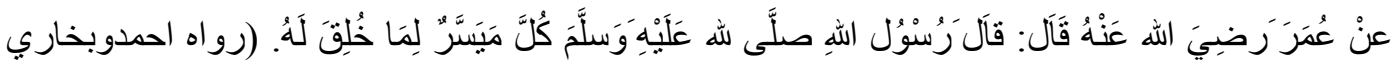

$$
\begin{aligned}
& \text { ومسلم وابو دودواترمذي) }
\end{aligned}
$$

Artinya: "Setiap sesuatu dimudahkan sesuai demnga takdir penciptanya" (HR. Ahmad, Bukhari, Muslim, Abu Daud dan At-tarmidzi). 
Sehubungan dengan itu, maka salah satu tujuan yang tidak boleh dilupakan oleh para orang tua muslim dalam mendidik anaknya ialah bertujuan mengharap ridho Allah. Hal tersebut sebagai ungkapan rasa syukur kepada-Nya atas karunia yang Dia berikan berupa lahirnya seorang anak dan sekaligus sebagai pertanggung jawaban dalam mengemban amanat yang Dia amanatkan.

\section{Pendidikan Keluarga}

Menurut Zakiyah Drajat orang tua merupakan pendidik utama dan pertama bagi anakanak mereka, karena dari merekalah anak mula-mula menerima pendidikan. ${ }^{6}$ Demikian juga menurut Andreas Harefa sebagaimana ia menyimpulkan dari pendapatnya Cak Nur mengatakan bahwa:

Hubungan antara orang tua dan anak yang demikian intim tidaklah mungkin digantikan secara total oleh lembaga-lembaga persekolahan, termasuk universitas. Bahkan sekolahsekolah agamapun tidak mungkin menggantikan sepenuhnya peran dan tanggung jawab orang tua. Institusi formal yang memberikan ajaran-ajaran yang bersifat umum maupun agama hanya mungkin meringankan beban tanggung jawab orang tua, tetapi tidak dapat dan tidak boleh diharapkan untuk menggantikan peran dan tanggung jawab orang tua secara keseluruhan.

Dari pernyataan ini dapat kita ketahui bahwa kehidupan keluarga merupakan lapangan pendidikan yang sangat urgen dalam membentuk dan mengarahkan kepribadian anak supaya menjadi manusia atau generasi yang berguna bagi agama dan bangsa. Dan orang tuanya merupakan pangkal pendidik yang akan banyak mempengaruhi pertumbuhan dan perkembangan anak lebih lanjut. Disadari atau tidak itu adalah merupakan tanggung jawab orang tua yang dibebankan oleh Tuhan kepada mereka. Dan sementara itu menurut Hasbullah (2003:198) tugas utama dari keluarga bagi pendidikan anak ialah sebagai peletak dasar bagi pendidikan akhlak dan pandangan hidup beragama.

Sementara itu di dalam UU No. 20 Tahun 2003 tentang Sisdiknas pasal 7 ayat 2 menyatakan bahwa orang tua dari usia wajib belajar, berkewajiban memberikan pendidikan dasar kepada anaknya. Hal ini juga diperkuat dengan pasal 27 ayat 1 menyatakan bahwa

\footnotetext{
${ }^{6}$ Zakiyah Daradjat, 1996, Ilmu Pendidikan Islam, Jakarta; Bumi Aksara, hal.35

${ }^{7}$ Andrias Harefa, 2001, Pembelajaran Diera Serba Otonom, Jakarta; Kompas, hal.47

Jurnal Auladuna | 132

Vol. ㄱ. No. [2. Iktober 2019
} 
Urgensitas Keluarga Dalam Menanamkan Nilai-Nilai

kegiatan pendidikan informal yang dilakukan oleh keluarga dalam lingkungan berbentuk kegiatan belajar secara mandiri.

Dari penjelasan di atas dapat kita ketahui bahwa orang tua mempunyai peran dan tanggungjawab yang besar terhadap pendidikan anak-anaknya. Oleh karena itu orang tua harus betul-betul mampu memberikan dasar-dasar keagamaan pada anak secara maksimal serta mampu memberikan tauladan yang baik bagi diri anak. Sebab anak akan cenderung mencontoh atau mengikuti segala perbuatan yang dilakukan oleh pihak orang tua.

\section{Nilai-Nilai Pendidikan Agama Islam}

Untuk membentuk anak yang shaleh dan shalehah serta mempunyai kepribadian yang baik, yakni anak yang menjalin hubungan baik dengan Allah dan sesama makhluk lainnya, maka pokok-pokok yang harus di berikan tiada lain adalah nila-nilai pendidikan agama Islam itu sendiri. Yang mana nilai-nilai pendidikan agama Islam itu tercover dalam ajaran Islam itu sendiri.

Menurut para ulama sebagaimana yang dikutip oleh Nipan Abdul Halim ajaran Islam secara garis besar dapat dikelompokkan menjadi tiga yakni: akidah, ibadah, dan akhlak. ${ }^{8}$

Begitu juga Yusuf Ali Anwar dalam bukunya study Agama Islam menyatakan bahwa ajaran-ajaran Islam secara garis besar terhimpun dan terklasifikasi dalam tiga hal pokok yakni akidah, ibadah dan akhlak. 'Dengan demikian menjadi jelas bahwa pokok-pokok pendidikan yang harus ditanamkan atau diberikan pada anak sedikitnya harus meliputi pendidikan akidah, pendidikan ibadah, pendidikan akhlak. Karena ketiga pokok ajaran Islam tersebut sebenarnya sudah mencakup aspek kehidupan manusia secara universal.

Menurut Hasan Basri dalam bukunya keluarga sakinah berpendapat bahwa ajaran agama dengan tuntunan akhlak dan ibadah serta akidah jika dilaksanakan sungguh-sungguh akan mampu menghasilkan perkembangan anak yang saleh yang mampu membahagiakan keluarga. ${ }^{10}$ Di antara peranan keluarga dalam menanamkan nilai-nilai pendidikan agama Islam pada diri anak semenjak usia dini adalah sebagai berikut:

\footnotetext{
${ }^{8}$ Abdul Halim Nipan, 2003, Anak Saleh Dambaan Keluarga, Yogyakarta; Mitra Pustaka, hal.911

${ }^{9}$ Yusuf, Anwar, Ali, 2003, Studi Agama Islam Untuk Perguruan Tinggi, Bandung; Pustaka Setia, hal.107

${ }^{10}$ Hasan Basri, 1999, Keluarga Sakinah Tinjauan Psikologi Dan Agama, Yogyakarta; Pustaka Pelajar, hal.89

Vol. Dl. No. Q2. Oktober 2019 
Asnawan

\section{Nilai-Nilai Akidah}

Akidah Islam dalam Al-qur'an disebut iman ia bukan hanya berarti percaya melainkan keyakinan yang mendorong seorang muslim untuk berprilaku. Karena itu lapangannya sangat luas bahkan mencakup segala sesuatu yang dilakukan seorang muslim yang disebut dengan amal shaleh. Oleh karena itu iman sendiri didefinisikan Abu Hanifah sebagai berikut:

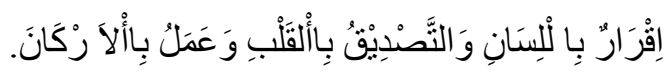

Artinya: "Mengucapkan dengan lisan membenarkan dengan hati mengerjakan dengan badan". (Asmaran, 1994, 71)

Menurut Toto Suryana Akidah adalah dasar pokok kepercayaan seorang muslim yang bersumber dari ajaran Islam yang harus dipegang sebagai sumber keyakinan yang mengikat. Di dalam kehidupan, akidah mempunyai peranan dan implikasi di dalam kehidupan manusia. Hal ini sebagaimana yang dikatakan oleh Yusuf Anwar bahwa implikasi tersebut dapat diketahui dari sikap dan penyerahan diri secara total pada Allah, memiliki keberanian untuk berbuat serta dapat membentuk rasa optimis dalam menjalani hidup. ${ }^{11}$

Karena akidah merupakan unsur yang paling urgen bagi manusia, maka pendidikan akidah seharusnya ditanamkan mulai sejak dini, karena dengan pendidikan akidah inilah anak akan mengenal siapa Tuhannya, bagaimana cara bersikap terhadap Tuhannya, dan apa saja yang mesti di perbuat dalam hidupnya. Hal ini senada dengan apa yang dikatakan oleh Nasruddin Razak dalam bukunya Dienul Islam bahwa doktrin akidah atau tauhid bagi kehidupan manusia menjadi sumber kehidupan jiwa dan pendidikan kemanusiaan yang tinggi. Tauhid akan mendidik jiwa manusia untuk mengikhlaskan kehidupannya pada Allah.

Dengan demikian dapat kita ketahui bahwa pendidikan akidah akan mampu membentuk karakter anak menjadi baik dalam kehidupannya. Oleh karena itu orang tua harus betul-betul menanamkan nilai akidah ini dengan baik, sebab sebagaimana yang telah disebutkan di atas bahwa setiap anak manusia pastilah terlahir dengan membawa fitrah Islamiyah. Semenjak ia lahir ia telah terbekali benih ketauhidan dari sisi Allah.

${ }^{11}$ Yusuf, Anwar, Ali, 2003, Studi Agama Islam Untuk Perguruan Tinggi, Bandung; Pustaka Setia, hal. 137 
Urgensitas Keluarga Dalam Menanamkan Nilai-Nilai

Maka kewajiban orang tua muslim hanyalah menyelamatkan benih tauhid itu dengan memberinya materi pendidikan akidah yang tepat.

Menurut Abdul Halim Nipan di antara beberapa hal yang perlu ditanamkan pada anak yang berkenaan dengan akidah adalah:

1. Membaca Kalimat Tauhid

Diutusnya nabi kedunia inin tidak lain adalah untuk menyampaikan misi Tuhan yang terformulasi dalam bentuk dua kalimat Syahadat sebagaimana disabdakan Nabi:

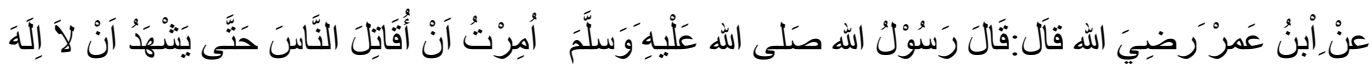

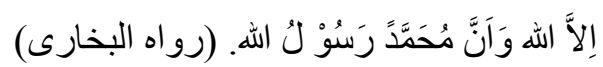

Artinya: "Aku (Muhammad) diutus untuk menerangi umat manusia sampai mereka bersaksi bahwa suatupun yang wajib dipertuhan selain Allah dan bersaksi bahwa Muhammad adalah utusan Allah" (HR. Buhkari). ${ }^{12}$

Nabi Muhammad dalam menyampaikan misi tersebut membutuhkan rentang waktu yang relatif panjang dan penuh dengan beribu macam tantangan. Ini menunjukkan bahwa betapa akidah Islam amat urgen bagi kehidupan manusia dalam kerangka sebagai medium menuju Tuhannya terlebih lagi bagi kehidupan anak.

Menurut Rasulullah sebagaimana yang dikutip Jalaluddin fungsi dan peran orang tua mampu untuk membentuk arah keyakinan anak-anak mereka. Menurut beliau, “setiap bayi yang dilahirkan sudah memiliki potensi untuk beragama, namun bentuk keyakinan agama yang akan dianut anak sepenuhnya tergantung dari bimbingan, pemeliharaan, dan pengaruh kedua orang tua mereka". ${ }^{13}$

Oleh karena itu dasar akidah harus terus menerus ditanamkan agar setiap pertumbuhan dan perkembangannya dilandasi dengan akidah yang benar.

2. Menanamkan Nilai Kecintaan Kepada Allah Dan Rasulnya

Kaitannya dengan penanaman pendidikan akidah bagi anak salah satunya adalah menanamkan rasa cinta pada Allah dan Rasulnya. Dalam hal ini Rasul bersabda:

\footnotetext{
${ }^{12}$ Halim Abdul Nipan, 2003, Anak Saleh Dambaan Keluarga, Yogyakarta; Mitra Pustaka.

${ }^{13}$ Jalaluddin, 2003, Psikologi Agama, Jakarta; PT. Raja Grafindo Persada, hal.216

Vol. ㅁI. №. 02. Dktober 2019 


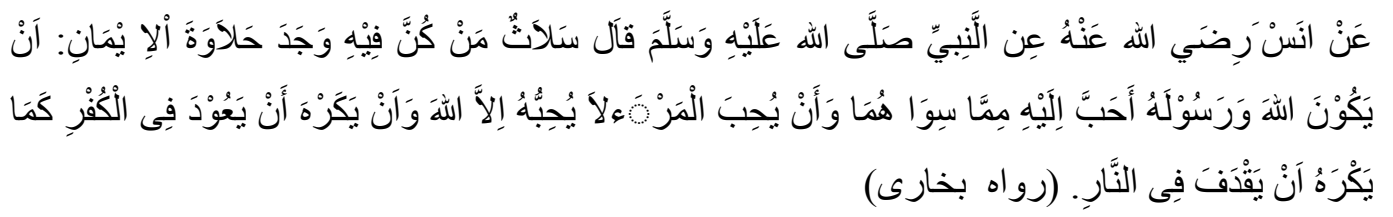

Artinya: "Tiga hal yang barang siapa memiliki ketiganya maka dia akan menemukan lezatnya iman, yakni: 1). Allah dan Rasulnya lebih dicintai dari pada yang lain, 2). Mencintai seseorang hanya karena Allah, 3). Dan berpantang tidak akan kembali ke kafir sebagaimana ia berpantang enggan dilemparkan ke neraka" (HR. Bukhari)

Penanaman rasa cinta pada Allah dan Rasulnya mulai sejak dini pada diri anak di dalam keluarga amatlah penting. Agar nantinya mereka bisa mengerti betul siapa Tuhannya dan siapa Nabinya. Kalau mereka sudah mengenal Allah dan Rasulnya kemudian dilanjutkan dengan bentuk implementasi yang bersifat praktis. Nah implementasi yang bersifat praktis ini akan tergambar dalam bentuk perilaku ibadah, yang mana ibadah sendiri merupakan bukti kecintaan mereka kepada Allah dan Rasulnya.

\section{Nilai-Nilai Ibadah}

Ibadah, sebagaimana yang dikatakan oleh Toto Suryana merupakan penghambaan seorang manusia kepada Allah sebagai pelaksanaan tugas hidup selaku makhluk. Ibadah di sini meliputi ibadah khusus atau ibadah mahdhoh dan ibadah umum atau ibadah ghoir mahdhoh. ${ }^{14}$

Seperti yang kita tahu bahwa tidak ada sesuatupun yang diciptakan Allah ataupun segala sesuatu kebijakan-kebijakan yang datang dari Allah untuk segala mahluknya yang lepas dari nilai-nilai kebaikan ataupun hikmah. Begitupula dengan ajaran ibadah. Menurut Yusuf Anwar di dalam Al-qur'an pun dijelaskan bahwa segala bentuk ibadah yang dilakukan oleh umat manusia akan melahirkan suatu kemaslahatan untuk kepentingan manusia itu sendiri. Melihat betapa pentingnya kegiatan ibadah bagi kemaslahatan manusia sendiri maka sudah semestinya orang tua selaku pendidik bagi anak-anaknya untuk mengajarkan dan menanamkan nilai-nilai ibadah itu sendiri.

Materi pendidikan ibadah ini secara menyeluruh oleh para ulama dikemas dalam sebuah disiplin ilmu yang disebut ilmu fiqh. Tata peribadatan yang konprehensif sebagaiman

${ }^{14}$ Suryana, Toto, et. al, 1997, Pendidikan Agama Islam, Bandung; Tiga Mutiara. hal.111 Jurnal Auladuna | 136

Vol. 미. No. Q2. Qktober 2019 
Urgensitas Keluarga Dalam Menanamkan Nilai-Nilai termaktub di dalam fiqh Islam itu hendaklah diperkenalkan mulai awal dan sedikit demi sedikit dibiasakan dalam diri anak. Menurut Zakiyah Darajat, anak yang masih kecil, kegiatan ibadah yang lebih menarik baginya adalah yang mengandung gerak sedangkan pengertian tentang ajaran agama belum dapat dipahaminya. ${ }^{15}$

Oleh karena itu di samping anak diberi sedikit pemahaman tentang ibadah juga harus dituntun sedikit demi sedikit, sehingga hal itu menjadi kebiasaan pada dirinya, dan teramalkan terus menerus dengan baik. Di antara berbagai nilai ibadah yang harus diajarkan dengan baik di antaranya Menurut Yusuf Anwar adalah sebagai berikut: mengajarkan Alqur'an, mengajarkan sholat mengajarkan puasa, mengajarkan zakat, dan mengajarkan haji. ${ }^{16}$

\section{Mengajarkan Al-Qur'an}

Al-Qur'an merupakan kitab Allah yang khusus diturunkan kepada Nabi Muhammad. Al-Quran diturunkan oleh Allah kepada Nabi Muhammad, agar dapat dijadikan suatu pedoman. Oleh karena itu, mengajarkan Al-Qur'an pada anak mulai sejak dini memang sangat dianjurkan karena Al-Qur'an sendiri merupakan kitab Allah yang berisi tentang informasi-informasi, aturan-aturan dan hukum-hukum dari Allah bagi manusia. Kitab-kitab Allah itu menjadi pedoman hidup manusia didunia agar hidup, manusia teratur, tentram serta bahagia. Karena tanpa adanya pedoman hidup, maka kehidupan manusia akan terombang-ambing dan tidak akan menemui jalan hidup yang lebih baik.

Ibnu Khaldun sebagaimana yang dikutip oleh Abdullah Nashih, mengisyaratkan tentang pentingnya mengajarkan dan menyuruh menghafalkan Al-Qur'an pada anak kecil. Ia menjelaskan bahwa “mengajarkan Al-qu'an merupakan dasar pengajaran dalam semua sistem pengajaran di berbagai negara Islam, karena hal itu merupakan

\footnotetext{
${ }^{15}$ Daradjat, Zakiyah, et,al, 1996, Ilmu Pendidikan Islam, Jakarta; Bumi Aksara, hal.60

${ }^{16}$ Yusuf, Anwar, Ali, 2003, Studi Agama Islam Untuk Perguruan Tinggi, Bandung; Pustaka Setia, hal.158

Vol. DI. №. Q2. Oktober 2019

Jurnal Auladuna | 137
} 
salah satu syiar agama yang akan berpengaruh terhadap proses pemantapan aqidah dan meresapnya iman". ${ }^{17}$

\section{Mengajarkan Sholat}

Ibadah sholat merupakan ibadah yang paling istimewa kedudukannya ketimbang ibadah-ibadah yang lainnya. Hal ini terbukti dengan diterimanya langsung ibadah ini, sementara ibadah-ibadah yang lainnya cukup disampaikan kepada Nabi melalui wahyu yang disampaikan oleh malaikat Jibril. Jadi, dari sini jelas bahwa shiolat mempunyai tujuan kebahagiaan manusia sendiri dalam mengarungi kehidupan dunia lebih-lebih kehidupan akhirat kelak.

Dengan demikian dapat kita pahami bahwa sholat merupakan indikasi tegak atau tidaknya seseorang dalam beragama, semakin baik sholat seseorang akan semakin tegak pula aqidah Islamiahnya. Sholat juga merupakan ibadah yang paling pokok yang menjadi ciri antara orang muslim dan kafir, ibadah yang bersifat ritual ini menyimpan makna yang besar bagi setiap muslim yang melaksanakannya. Menurut Toto shalat mengandung makna pembinaan pribadi yaitu dapat menghindar dari perbuatan dosa dan kemungkaran.

Karena shalat di sini merupakan sesuatu yang fundamental, maka sejak usia dini harus diperkenalkan dan dianjurkan pada anak. Dalam hal ini orang tua seharusnya dapat menuntun dan mengajarkan sholat pada diri anak mulai sejak usia kecil dengan cara selalu mengajak anak untuk selalu melakukan ibadah sholat. Dan apabila anak sudah menginjak usia tujih tahun, orang tua harus bisa memerintahkan anak-anaknya untuk selalu melakukan sholat lima waktu. Dan apabila hingga usia sepuluh tahun ia masih belum mengerjakan sholat maka orang tua harus bisa menghukum anak-anaknya. Tentunya yang dimaksud hukuman dalam hal ini adalah hukuman yang mendidik.

Sehubungan dengan diperintahkannya shalat semenjak anak berusia tujuh tahun, maka sejak itu pula anak harus diberi pengetahuan secukupnya tentang hal ihwal

${ }^{17}$ Ulwan, Nashih Abdullah, 1996, Pemeliharaan Kesehatan Jiwa Anak, Bandung, PT. Raja Rosda Karya, hal.46 
Urgensitas Keluarga Dalam Menanamkan Nilai-Nilai seputar shalat. Namun yang terpenting dalam hal ini pemberian teladan dari fihak orang tua.

\section{Mengerjakan Puasa}

Menurut Toto Suryana Puasa merupakan ibadah ritual yang memiliki makna tinggi ini merupakan suatu proses pendidikan dan latihan yang intensif menuju kekuatan iman dan sekaligus mengendalikan hawa nafsu. Ibadah ritual ini dapat merlahirkan sifat-sifat positif yang ditampakkan dalam kehidupan sehari-hari. ${ }^{18}$ Seperti keperdualian terhadap fakir miskin, ia merasakan betapa lapar dan hausnya tidak makan dan minum, sementara banyak orang yang lapar dan haus karena miskinnya.

Begitu juga Nasruddin Razak menyatakan bahwa "berbagai latihan mental yang ditempatkan puasa ia mendidik manusia berjiwa besar sanggup mengatasi segala macam kesulitan dan cobaan hidup dan menumbuhkan sifat sabar pada diri manusia”. Di samping itu pula puasa melatih menahan dan mengendalikan diri dari keinginan dan dorongan-dorongan untuk melakukan perbuatan-perbuatan yang dilarang Allah.

4. Mengajarkan Zakat

Menurut Toto Suryana Zakat meiliki fungsi sebagai pelaksanaan perintah Allah sekaligus merupakan cara membersihkan dan penyuciaan harta yang dimilikinya. Namun pada prinsipnya zakat merupakan bentuk penyantunan terhadap kaum dhuafa', baik harta itu diberikan secara langsung dalam bentuk konsumtif maupun dengan cara diarahkan pada kegiatan produktif untuk meningatkan kemampuan ekonomi yang lemah, sehingga mereka dapat keluar dari jurang kemiskinan. Di samping itu menurut Nasruddin Razak Zakat mengandung berbagai hikmah yang tinggi yaitu: 1). Sebagai manefestasi rasa syukur pada Allah, 2). Mendidik dan membersihkan rohani manusia seperti kikir, rakus dan sebagainya, 3). Menunjukkan bahwa zakat merupakan sifat perjuangan Islam yang selalau berorientasi kepada

${ }^{18}$ Suryana, Toto, 1997, Pendidikan Agama Islam, Bandung; Tiga Mutiara, hal.118 Vol. ㅁ. No. 02. Oktober 2019 
kepentingan kaum dhuafa'. ${ }^{19}$ Karena zakat sendiri mengandung unsur sosial yang tinggi di samping perintah Allah sebagaimana yang telah di terangkan di atas, maka sudah selayaknya hal itu diajarkan pada diri anak agar dapat mendidik jiwa mereka untuk selalu melakukan pengorbanan dan mempunyai rasa sosial yang tinggi terhadapa orang lain yang tidak mampu.

\section{Mengajarkan Haji}

Haji, sebagaimana yang dikatakan oleh Toto Suryana merupakan ibadah ritual yang sarat dengan makan simbolik, mendorong lahirnya prilaku yang menjadi tujuan setiap orang. ${ }^{20}$ Haji mabrur merupakan titik harapan bagi setiap orang yang melaksanakan ibadah haji karena haji mabrur pada dasarnya adalah membekasnya ritual haji dalam kehidupan sehari-hari, setelah ibadah haji dilakukan.

Di samping itu pula ibadah haji merupakan ibadah yang diwajibkan oleh Tuhan pada manusia yang sekiranya mampu. Karena ibadah haji merupakan ibadah yang disyariatkan oleh Tuhan maka wajib bagi kita mengajarkannya pada anak-anak kita, minimal mereka tahu tentang kewajiban itu. Seluruh tata peribadatan yang telah diserbutkan diatas hendaknya diperkenalkan dan diajarkan secara intensif pada diri anak dan sedikit-demi sedikit dibiasakan agar kelak mereka tumbuh menjadi insan yang benar-benar bertakwa yakni insan yang taat melaksanakan segala perintah Allah dan menjauhi larangannya.

\section{Nilai-Nilai Akhlak}

Menurut Mahjuddin Akhlak dalam Islam merupakan sendi yang ketiga setelah akidah dan syari'ah (ibadah) dengan fungsi yang selalu mewarnai sikap dan prilaku manusia dalam memanifestasikan keimanannya, ibadah serta muamalahnya terhadap sesama manusia. $^{21}$

Suatu hal yang tidak diragukan bahwa keutamaan akhlak, keutamaan tingkah laku, dan naluri merupakan salah satu buah iman yang meresap dalam pertumbuhan keagamaan yang sehat. Maka, seorang anak jika sejak dini ditumbuh besarkan atas dasar keimanan

${ }^{19}$ Razak, Nasruddin, 1973, Dienul Islam, Bandung; PT. Al ma'arif, hal.249

${ }^{20}$ Suryana, Toto, 1997, Pendidikan Agama Islam, Bandung; Tiga Mutiara, hal. 121

${ }^{21}$ Mahjuddin, 1999, Kuliah Ahklak Tasawuf, Jakarta; Kalam Mulia, hal.138 
Urgensitas Keluarga Dalam Menanamkan Nilai-Nilai

kepada Allah, terdidik untuk takut kepadanya, niscaya ia akan punya kemampuan fitri dan akan terbiasa dengan ahklak mulia.

Dari sini kita tahu bahwa seorang anak memerlukan pendalaman dan penanaman nilainilai norma dan akhlak kedalam jiwa mereka. Karena menurut Syech Mustafa AlGhulayani dalam bukunya Idhatun na Syiin sebagaimana yang dikutip oleh Abu Ahmadi mengatakakan bahwa: "Sesungguhnya anak-anak itu akan menjadi orang dimasa mendatang apabila anak di biasakan berakhlak yang baik, perangainya menjadi meninggi dan dengan ilmunya akan berdaya guna bagi negaranya, merekalah fundamen yang kokoh untuk membangkitkan umat. $^{22}$ Di sinilah tugas orang tua untuk selalu menanamkan nilai-nilai mulia kedalam jiwa anak-anak mereka dan menyucikan kalbu mereka dari kotoran. Dari pentingnya masalah ahklak ini sampai-sampai Husain Mazhahiri menyatakan bahwa "sepertiga dari kandungan Al-Qur'an baik secara langsung atau tidak telah membahas sekitar masalah akhlak" ${ }^{23}$. Begitupun sabda Nabi:

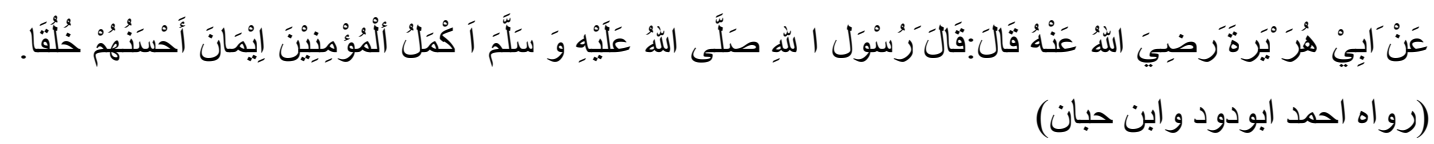

Artinya; "Orang mukmin yang paling sempurna imannya ialah mereka byang paling mulia akhlaknya"(HR. Abu Daud dan Ibnu Hibban)

Dengan demikian, maka dalam rangka menyelamatkan dan memperkokoh akidah islamiyah anak, pendidikan anak harus dilengkapi dengan pendidikan ahklak yang memadai, sehingga dikemudian hari kesalehan anak betul-betul dapat diharapkan. Karena selain harus pandai berhubungan baik dengan sang pencipta kesalehan anak harus pula dilengkapi dengan ahklakul karima dalam berhubungan dengan sesama manusia dan lingkungannya.

Pendidikan akhlak yang memadai ini seharusnya di mulai terhadap anak sejak kecil hal ini sesuai dengan apa yang dikatakan oleh Ibnul Jauzi dalam bukunya At-tib Ar-rohani sebagaimana yang dikutip oleh Dr. Muhammad Athiyah Al-Abrosyi (2003: 116) bahwa:

"Pembentukan yang utama ialah diwaktu kecil apabila seseorang anak di biarkan melakukan sesuatu (yang kurang baik) sehingga dan telah menjadi

${ }^{22}$ Ahamadi, Abu, 2001, Ilmu Pendidikan, Jakarta; Rineka Cipta, hal.120

${ }^{23}$ Mazhahiri, Husain, 2003, Pintar Mendidik Anak, Jakarta; Lentera Basritami, hal.240 Vol. I. №. [2. Oktober 2019 
kebiasaannya, sukarlah meluruskannya. ${ }^{24}$ Artinya "pendidikan budi pekerti yang tinggi wajib di mulai di ruma, dalam keluarga, sejak kecil dan jangan membiarkan anak-anak tampa pendidikan, bimbingan, dan petunjuk". Bahkan, sejak kecil ia harus didik sehingga tidak terbiasa dengan adat dan kebiasaan yang kurang baik, sehingga sukarlah mengembalikannya dan memaksanya untuk meninggalkan kebiasaan tersebut. Ringkasnya, pemeliharaan lebih baik dari perawatan".

Sementara Drs. A. Toto Suryana membagi ahklak menjadi tiga bagian yaitu 1). Ahklak terhadap Allah 2). Ahklak terhadap sesama manusia 3). Ahklak terhadap lingkungan. ${ }^{25}$

a. Ahklak Terhadap Allah

Akhlak yang baik pada Allah berucap dan bertingkah laku yang terpuji pada Allah baik melalui ibadah langsung pada Allah seperti sholat, puasa dan sebagainya, maupun melalui prilaku tertentu yang mencerminkan hubungan atau komunikasi dengan Allah diluar ibadah itu. Berahklak yang baik antara lain beriman, taat, ihklas, husnudzan, tawakal, syukur, dan lain-lain.

b. Ahklak Terhadap Manusia

Manusia dalam hidup bermasyarakat perlu adanya tatanan yang tepat mengarahkan pada suatu kebaikan bersama. Oleh karena itu di dalam buku etika Islam sebagaimana ynag di rumuskan oleh Tim akhlak disebutkan bahwa "semua sifat, prilaku dan ahklak harus kita perhatikan dengan sungguh-sungguh dalam berhubungan dengan masyarakat, sifat-sifat terpuji yang harus diterapkan dan sifat-sifat tercela harus kita jauhi inilah yang disebut dengan ahklak pergaulan", ${ }^{26}$

Sementara itu menurut Muhammad Daud dalam bukunya pendidikan agama Islam, bahwa akhlak terhadap manusia dapat dirinci menjadi: 1). Akhlak terhadap Rasul; antara lain: mencintainya secara tulus dengan mengikuti semua sunnahnya. 2). Akhlak terhadap ortu tua; antara lain: mencintai mereka, merendahkan diri padanya, berkomunikasi dengan baik. 3). Akhlak terhadap diri sendiri; antara lain: jujur, ikhlas, sabar, rendah hati. 4). Akhlak terhadap tetangga; antara lain: saling mengunjungi, saling

${ }^{24}$ Al-Abrasyi, athiyah Muhammad, 2003, Prinsip-prisip Dasar Pendidikan Islam, Bandung; Pustaka Setia

${ }^{25}$ Toto Suryana, 1997, Pendidikan Agama Islam, Bandung; Tiga Mutiara, hal.188

${ }^{26}$ Tim Ahklak, 2003, Etika Islam Dari Kesalehan Individual Menuju Kesalehan Sosial, Jakarta; Al-huda, hal.54

Jurnal Auladuna | 142

Vol. ㄱ. No. 02. Qktober 2019 
Urgensitas Keluarga Dalam Menanamkan Nilai-Nilai

bantu, saling hormat. 5) Akhlak terhadap masyarakat; antara lain: memuliakan tamu, menghormati nilai dan norma yang berlaku, saling tolong. ${ }^{27}$

c. Akhlak Terhadap Lingkungan

Seseorang muslim memandang alam sebagai milik Allah yang wajib di syukuri dengan cara mengelolanya dengan baik agar bermanfaat bagi manusia dan bagi alam itu sendiri. Sireger (1999: 93) berpendapat di dalam bukunya Islam untuk berbagai aspek kehidupan bahwa: "Allah telah menjadikan alam ini untuk manuisia dan untuk dimanfaatkan sesuai de ngan ridha Allah tidak untuk dirusak dan untuk berbuat binasa. ${ }^{28}$ Dalam hal ini Allah berfirman:

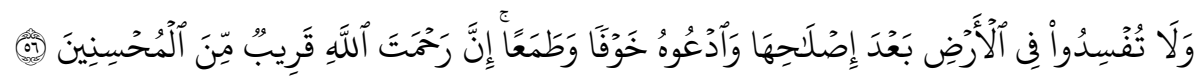

Artinya: "Dan janganlah kamu berbuat binasa di bumi sesudah dijadikan baik dan berdo'alah kepada Allah dengan takut (kepada siksanya) dan menuntut (kasihnya) sesungguhnya rahmat Allah dekat dengan orang-orang yang berkebajikan". (Al-A'raf: 56) (Depag, 1989: 230)

Pemanfaatan alam dan lingkungan hidup bagi kepentingan manusia hendaknya disertai sikap tanggung jawab untuk menjaganya agar tetap utuh dan lestari. Berakhlak pada lingkungan alam adalah menyikapinya dengan cara memelihara kelangsungan hidup dan kelestariaannya. Agama Islam menekankan agar manusia mengendalikan dirinya dalam mengeksploitasi alam. Sebab alam yang rusak akan merugikan bahkan menghancurkan kehidupan manusia.

Dari ketiga komponen pembagian akhlak diatas seharusnya diajarkan dan dibiasakan pada kehidupan anak sehari-hari agar mereka dapat terbiasa berlaku baik dalam hidupnya, kalau ke sholehan personal sudah terbentuk, maka kami yakin kesholehan sosialpun akan terbentuk, karena pada dasarnya kehidupan sosial adalah manifestasi dari kehidupan personal manusia.

\section{KESIMPULAN}

\footnotetext{
${ }^{27}$ Muhammad Daud Ali, , 1998, Pendidikan Agama Islam, Jakarta; PT. Raja Grafindo Persada, hal.157

${ }^{28}$ Aziz, Mahmud, Siregar, 1999, Islam Untuk Berbagai Aspek Kehidupan, Yogyakarta; Tiara Wacana
}

Vol. I. No. Q2. Iktober 2019 
Asnawan

Pendidikan akidah pada anak di dalam kelauarga diberikan sudah diupayakan oleh keluarga mulai anak lahir. Selanjutnya pendidikan akidah diberikan pada anak melalui nasehatnasehat ataupun cerita-cerita menurut perkembangan fase usia anak. Sementara bagi keluarga yang kurang mampu dalam pengetahuan agamanya, maka pendidikan anak diserahkan pada guru ngaji. Peranan keluarga dalam hal ini tidak lain sebagai motivator bagi anak. Peranan keluarga dalam menanamkan niali-nilai- ibadah pada anak di dalam keluarga amatlah besar. Peranan tersebut nampak pada usaha yang dilakuakan orang tua untuk selalu menanamkan nilai-nilai ibadah serta sekaligus melatih anak agar mempunyai kepribadian yang tinggi dalam menjalankan ibadahnya. Peranan keluarga dalam menanamkan nilai-nilai akhlak pada anak juga amatlah besar. Bentuk penanaman ini di mulai oleh orang tua mulai sejak dini. Karena pada masa ini adalah momentum yang tepat untuk melatih anak supaya memiliki akhlak yang baik. Sehingga di masyarakat selalu mendidik anak-anaknya agar berprilaku dan berbicara dengan baik, baik dilingkungan keluarga sendiri maupun luar lingkungan keluarga. Jika kebiasaan tersebut sudah terinternalisasi dalam jiwa anak mulai sejak dini, maka ketika ia besar kelak akan mempunyai jiwa yang terpuji.

\section{DAFTAR PUSTAKA}

Daradjat, Zakiyah,1996, Ilmu Pendidikan Islam, Jakarta; Bumi Aksara. Sisdiknas, 2003, UU. RI No. 20 Tabun 2003, Bandung; Citra Umbara. Jalaluddin, 2003, Psikologi Agama, Jakarta; PT. Raja Grafindo Persada. Hasbullah, 2003, Dasar-Dasar Ilmu Pendidikan, Jakarta; PT. Raja Grafindo Persada. Harefa, Andrias, 2001, Pembelajaran Diera Serba Otonom, Jakarta; Kompas.

Yusuf, Anwar, Ali, 2003, Studi Agama Islam Untuk Perguruan Tinggi, Bandung; Pustaka Setia.

Halim Abdul Nipan, 2003, Anak Saleh Dambaan Keluarga, Yogyakarta; Mitra Pustaka.

Jalaluddin, 2003, Psikologi Agama, Jakarta; PT. Raja Grafindo Persada.Yusuf, Anwar, Ali, 2003, Studi Agama Islam Untuk Perguruan Tinggi, Bandung; Pustaka Setia

Ulwan, Nashih Abdullah, 1996, Pemelibaraan Kesehatan Jiwa Anak, Bandung, PT. Raja Rosda Karya.

Razak, Nasruddin, 1973, Dienul Islam, Bandung; PT. Al ma'arif

Suryana, Toto, 1997, Pendidikan Agama Islam, Bandung; Tiga MutiaraMahjuddin, 1999, Kuliah Abklak Tasawnf, Jakarta; Kalam Mulia.

Ahamadi, Abu, 2001, Ilmu Pendidikan, Jakarta; Rineka Cipta.

Mazhahiri, Husain, 2003, Pintar Mendidik Anak, Jakarta; Lentera Basritami

Al-Abrasyi, athiyah Muhammad, 2003, Prinsip-prisip Dasar Pendidikan Islam, Bandung; Pustaka Setia

Suryana, Toto, et. al, 1997, Pendidikan Agama Islam, Bandung; Tiga Mutiara

Jurnal Auladuna | 144

Vol. ㄱ. №. 02. Iktober 2019 


\section{Urgensitas Keluarga Dalam Menanamkan Nilai-Nilai}

Tim Ahklak, 2003, Etika Islam Dari Kesalehan Individual Menuju Kesalehan Sosial, Jakarta; Al-huda Ali, Daud, Muhammad, 1998, Pendidikan Agama Islam, Jakarta; PT. Raja Grafindo Persada.

Aziz, Mahmud, Siregar, 1999, Islam Untuk Berbagai Aspek Kehidupan, Yogyakarta; Tiara Wacana Sardiman, 2003, Interaksi Dan Motivasi Belajar-Mengajar, Jakarta; PT. Raja Grafindo Persada. Hamalik, Oemar, 1999, Kurikulum Dan Pembelajaran, Jakarta; Bumi Aksara.

Hasbullah, 2003, Dasar-Dasar Ilmu Pendidikan, Jakarta; PT. Raja Grafindo Persada, hal.15 Daradjat, Zakiyah, 1996, Ilmu Pendidikan Islam, Jakarta; Bumi Aksara.

Halim Abdul Nipan, 2003, Anak Saleh Dambaan Keluarga, Yogyakarta; Mitra Pustaka. 